\title{
Effect of soil straw cover on evaporation, transpiration, and evapotranspiration in sugarcane cultivation
}

\author{
Kassio S. Carvalho*1, Murilo S. Vianna², Daniel S. P. Nassif ${ }^{3}$, Leandro G. Costa ${ }^{2}$, Marcos V. Folegatti ${ }^{2}$, Fábio \\ R. Marin ${ }^{2}$
}

${ }^{1}$ Department of Agricultural Engineering, Institut Federal of Mato Grosso, Sorriso, Mato Grosso, Brazil

2University of São Paulo (USP), College of Agriculture “Luiz de Queiroz" (ESALQ), Piracicaba-SP, Brazil

${ }^{3}$ Federal University of São Carlos, Campus Lagoa do Sino, Buri-SP, Brazil

*Corresponding author: kassio.carvalho@srs.ifmt.edu.br

\begin{abstract}
Residual straw affects the physical, chemical, and biological attributes of soil and can influence plant transpiration and the evaporation of water from the soil. Therefore, in this study, we evaluated the effect of straw on evaporation and transpiration of sugarcane. The experiment was conducted in a 2.5 ha area irrigated via a central pivot. The experiment consisted of two treatments, namely, with and without straw removal of soil. Evaporation was determined by means of equations and transpiration with sap flow sensors using the heat balance method. Evapotranspiration of the crop was measured using the Bowen ratio method and compared with the sum of the collected soil evaporation and transpiration data. On the basis of relationship analysis between the evapotranspiration of the crop measured using the Bowen ratio method and the sum of the sap flow combined with estimates of the evaporation of soil water, we obtained coefficient of determination values of 0.65 and 0.69 , and angular coefficients of 1.01 and 0.96 for treatments with and without straw, respectively. We accordingly found that the use of straw on the soil reduces the evaporation of soil water and increases the transpiration and evapotranspiration of the crop.
\end{abstract}

Keywords: Crop residue; irrigation; Saccharum officinarum L.; soil moisture; water consumption. Abbreviations: CP and SP with and without straw removal; DAC_Days after cutting.

Introduction

Sugarcane crop is the main source of sugar in the world, with significant social, economic and environmental importance in many tropical countries. Compared to other crops, it is the 6st most economically significant and the 2nd most important C4 species after maize (FAO, 2016). Globally, more than $70 \%$ of sugarcane are produced in Brazil, India, China, Thailand and Pakistan, with Brazil being the largest producer (50\% of the global production). Sugarcane is also used for the production of ethanol ("flexfuel" vehicles) and biomass energy (electricity and heating) (Walter et al., 2014). Sugarcane covers an area of about 8.8 million hectares in Brazil, with a total average production of 645 million tons per year. The state of São Paulo in Southern Brazil accounts for $50 \%$ of the national production (CONAB, 2017).

In the last decade, the mechanization and non-burning (green cane) harvesting systems, employed in practically all Brazilian sugarcane fields, have resulted in the maintenance of a layer of residue on the soil, the so-called "straw cover". Under the mechanized and raw sugarcane harvest systems, a large amount of waste accumulates over the soil, which can be a source of nutrients, reduces water lost through evaporation, and improves the sustainability of the production chain.
Straw cover management contributes to the cycling of soil nutrients (Van Antwerpen et al., 2002), the preservation of soil structure and physical and chemical properties (Graham, Haynes and Meyer, 2002) and can be related to a significant reduction of weeds (Leal et al., 2013) as well as to indirect yield increase (Gava et al., 2001; Kingston, 2014). Nonetheless, one of the most important effects is the maintenance of soil moisture by the reduction of evaporation, reaching a reduction of up to $200 \mathrm{~mm}$ per year (Denmead, Mayocchi and Dunin, 1997; Thorburn et al., 1999; Olivier and Singels, 2012). Despite the benefits of the straw cover in terms of soil health and water savings, new technologies of electricity and second-generation ethanol production (Dias et al., 2011) from crop residue have raised the questions of the optimal point between straw cover and energy production from crop residues.

The majority of Brazilian sugarcane areas are under rainfed conditions; thus, information to what extent the straw can preserve soil moisture an offsets the water stress is valuable for growers. Moreover, irrigated agriculture is under pressure to demonstrate that water resources are used efficiently, and it is possible that the retention of this layer of waste will interfere in evaporation and soil moisture levels, thereby altering irrigation management. Thus, it is important 
to gain a better understanding of the impact of maintaining this layer of residual waste on the cropping system in order improve the formulation of agricultural management strategies (Olivier and Singels, 2012).

The evaporation of soil water depends on the stage of crop development, meteorological conditions, soil moisture (maximum when the soil is saturated and as the soil dries evaporation becomes limiting) and the adopted management. Management practices that modify the soil surface, such as the retention of straw on the soil, influence, the soil temperature, incident radiation, surface texture and consequently affect evaporation.

Transpiration can be influenced by the same factors that affect the evaporation of the soil water, and also by physiological factors such as crop canopy architecture, canopy resistance, species, cultivar, and phenological phase. Transpiration can also be influenced by the characteristic of plant leaves, including dimensions, pigmentation, and mass, and biological factors that determine the number and distribution of stomata (Leuzinger et al., 2010).

In this study, we sought to evaluate the effect of residual straw on evaporation, transpiration, and evapotranspiration of sugarcane and we propose a soil water evaporation estimation model that can be used in conjunction with transpiration data to determine crop evapotranspiration. The quantitative understanding of the influence of straw on the water availability of soil, the evaporation of soil water, and the transpiration of sugarcane crop can aid growers on making decision. This knowledge could be useful to be included in process based crop models (Marin and Jones, 2014).

\section{Results and Discussion}

\section{Evaporation of water from the soil}

The evaporation of water from the soil planted with sugarcane along with cover of straw was lower than that observed in the SP area (Fig 1). We noted that precipitation or irrigation increased evaporation values due to increase in water content of the soil. According to Allen et al. (1998), the increase in evaporation occurs when the interval between rainfall and irrigation is large and the capacity of the soil to transmit water to the surface is small. Thus, the moisture in the surface layer of the soil is decreased and the surface becomes dry. Under these circumstances of limited water availability, the reduced water levels effectively control the evaporation of the soil. In the absence of any water supply to the soil surface, evaporation decreases rapidly, and can cease almost completely within a few days. Following precipitation, we verified that evaporation in the SP managed area increased at a considerably higher rate than that observed in the $\mathrm{CP}$ area. According to Peres et al. (2010), this difference can be attributed to the fact that the presence of straw on the soil surface may decrease the effects of solar radiation compared with the SP treatment, substantially reducing losses of water from the soil by evaporation. Allen et al. (1998) reported that the energy required for transforming water molecules from a liquid to vapor state (evaporation) and direct solar radiation are the main factors influencing soil evaporation, followed to a lesser extent by ambient air temperature. The driving force necessary to remove water vapor from an evaporating surface is determined by the difference between the water vapor pressure at the evaporating surface and that of the surrounding air. As the evaporation process is continuous, the surrounding air gradually becomes saturated and the process will eventual slow and could cease if the humid air is not transferred to the surrounding atmosphere. Replacing saturated air with drier air is largely dependent on wind speed. Consequently, solar radiation, air temperature, relative humidity, and wind speed are the climatic parameters to be considered by evaluating the evaporation process.

A further relevant aspect is that, from 65 days after cutting (DAC), rainfall was more frequent and evaporation was decreased each month thereafter. This may have occurred due to an increase in the LAl; thus, reducing the effect of the meteorological variables on the soil evaporation. According to Adams et al. (1976), the degree of shading from the crop canopy can also affect the evaporation process.

\section{Flow of sugarcane crop sap}

The accumulated flow of sap during the 9-day period of sugarcane in the managed area with $\mathrm{CP}$ was higher than in the SP area during the months of March, April, and early May 2015 (Table 2). Considering that, the number of sugarcane plants per hectare is approximately 130 thousand and the difference per period between the transpiration of the CP and SP managed areas would be 192.4 thousand liters per hectare. This emphasizes the importance of the effect of a soil cover on transpiration in a cane field. The evaporation of water from the leaf surface produces a movement of the water within the plant (sap flow) derived from the soil by the roots. According to Vasconcelos (2003), changes in the harvesting system from the manual burning of cane to the mechanized harvesting of raw cane reduces the thermal amplitude of the soil, and increases the content of water and organic matter in the soil. Thus, the presence of straw covers favor water absorption by plants, since it improves the soil structure and reduces the effect of climatic variables on evaporation of water from the soil.

From March to May 2015, the transpiration of sugarcane grown in the $\mathrm{CP}$ managed area was higher than that recorded in the SP area (Fig $2 A$ ). This difference may have been attributable to reduced evaporation due to the presence of straw (Fig 1), increasing soil water availability to the crop. During the day, the transpiration of sugarcane is highest between the hours of 14:00 and 15:00 (Fig 2B), because of the greater availability of energy and the prevailing vapor pressure deficit.

The CP and SP areas had mean transpiration rates of 1.32 and $0.99 \mathrm{~L} \mathrm{~m}^{-2}$ of green leaf $\mathrm{d}^{-1}$, respectively. Nassif et al. (2014), worked with the same sugarcane cultivar with stalks bearing approximately $0.34 \mathrm{~m}^{2}$ of leaf, and cultivated without soil cover from May $14^{\text {th }}$ to $30^{\text {th }}$ and from June $16^{\text {th }}$ to July $4^{\text {th }}$. They recorded an average transpiration rate of $1,52 \mathrm{~L} \mathrm{~m}^{-2}$ of $\mathrm{d}^{-1}$ green leaf. The smaller rate of transpiration recorded in the present study may be due to the different leaf area per stalk, and to the fact that we conducted our study at a different time of year (readings were performed from March $21^{\text {st }}$ to May $\left.6^{\text {th }}, 2015\right)$, and evidently with a difference in energy availability. 
Table 1. Chemical characterization of the soil of the experimental area.

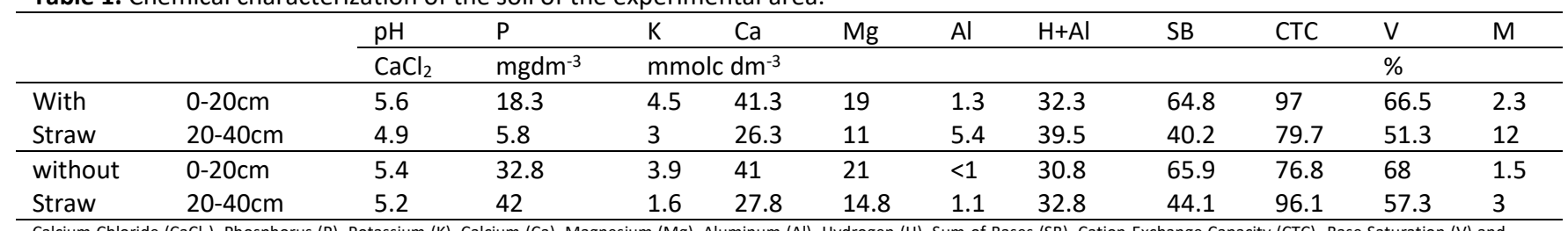

Calcium Chloride $\left(\mathrm{CaCl}_{2}\right)$, Phosphorus (P), Potassium (K), Calcium (Ca), Magnesium (Mg), Aluminum (Al), Hydrogen (H), Sum of Bases (SB), Cation Exchange Capacity (CTC), Base Saturation (V) and

Organic Matter (M).

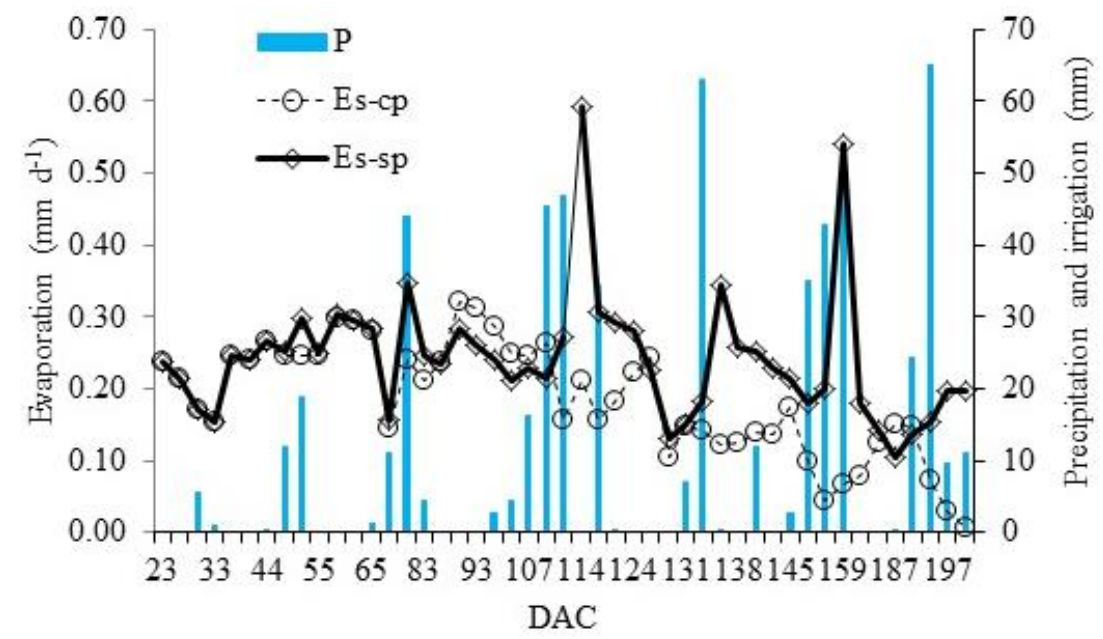

Fig 1. Accumulated precipitation and irrigation $(P)$ in the intervals between successive measurements of soil moisture, and evaporation of water from the soil, in a sugarcane field managed with straw (Es-cp) and without straw (Es-sp). Days after cutting (DAC).

Table 2. Synthesis of the values determined from an analysis of variance and Tukey's test $(p<0.05)$ for the accumulated transpiration during five 9-day periods.

\begin{tabular}{cc}
\hline Management & Transpiration (L stalk ${ }^{-1}$ period $^{-1}$ ) \\
\hline CP & 5.94 a \\
SP & $4.46 \mathrm{~b}$ \\
\hline C.V. (\%) & 16.5 \\
\hline
\end{tabular}

Different letters in the right-hand column signify a significant difference as determined by the Tukey test at $\mathrm{p}<0.05$. CP, area with straw cover; SP, area with no straw cover; C.V., coefficient of variation.
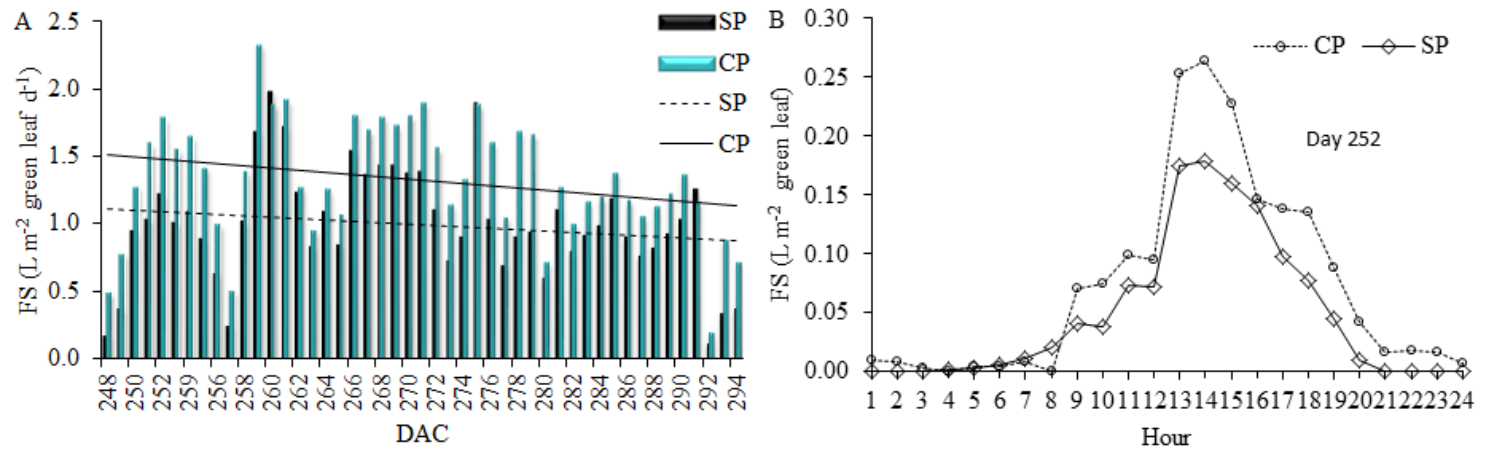

Fig 2. Sap flow (FS) of a cane field managed with (CP) and without (SP) a straw cover, from March $21^{\text {st }}$ to May $6^{\text {th }}, 2015$ (A), and hourly variation in sap flow on March 25th, 2015 (B). Days after cutting (DAC). 

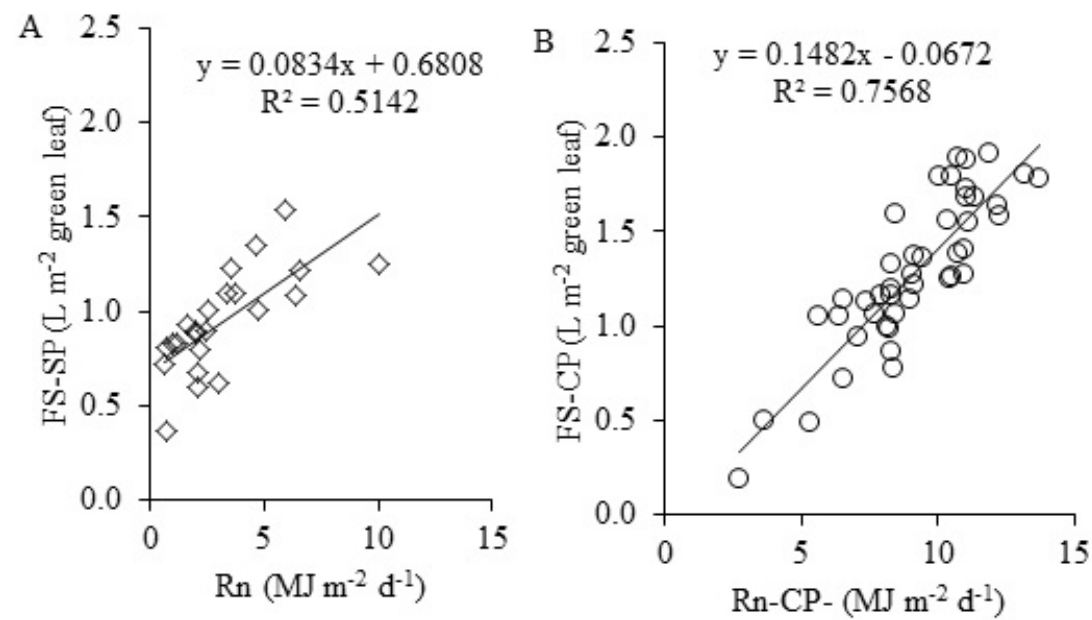

Fig 3. Relationship between radiation balance $(\mathrm{Rn})$ and sap flow $(\mathrm{FS})$ in a sugarcane field without straw cover (SP) (A) and with straw cover (CP) (B).
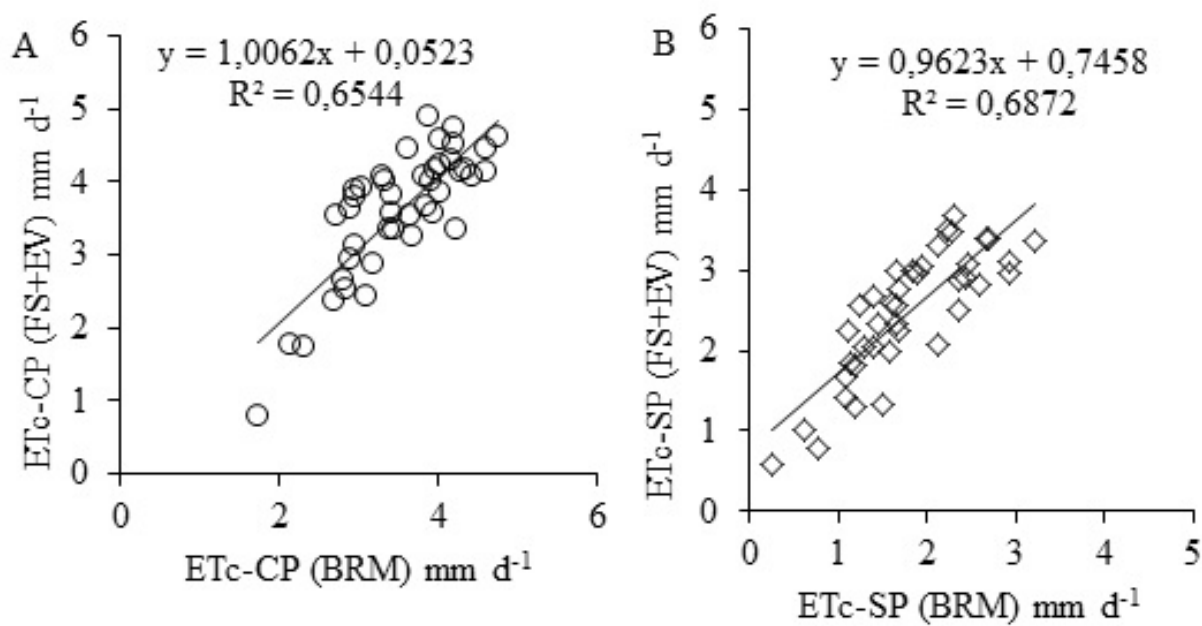

Fig 4. Relationship between the evapotranspiration of a sugarcane crop measured by Bowen ratio method (ETc-BRM) and obtained based on the sum of sap flow and the evaporation of water from the soil (FS+EV) of a cane field managed with a straw cover (CP) (A) and without a straw cover (SP) (B).

Analysis of sap flow in relation to the radiation balance $(\mathrm{Rn})$ of the CP and SP treatments showed a linear regression model, with sap flow increasing with increase in Rn (Fig 3). This indicates that the transpiration of sugarcane tends to increase when it has a high radiation balance combined with greater availability of water for the crop. According to Leuzinger et al. (2010), plant transpiration is a component of the energy balance that is influenced by environmental factors (solar radiation, air velocity, temperature, and relative humidity) and biological factors.

Another important observation made for the CP managed area is that crop transpiration associated with the Rn was related to an increase in the water content of the soil. As water becomes limiting, transpiration is reduced (Wang and Gartung, 2010). The high Rn values recorded in the CP area may have been related to the reflectance capacity of the straw.

One of the factors that contributes to the loss of water from sugarcane leaves is high Rn. According to Silva et al. (2013), the evapotranspiration of irrigated sugarcane in semi-arid regions of Brazil is more strongly controlled by the available energy, derived radiation balance, than by the interaction of the crop surface with the air of the growing environment, which is influenced by wind and the temperature and humidity of the air.

With regards to transpiration, the availability of energy is of fundamental importance. This can be illustrated by a study conducted by Chabot et al. (2005), who measured transpiration rates in a semi-arid region of Morocco, with an average water consumption of $8 \mathrm{~mm} \mathrm{day}^{-1}$. The authors infer that the measurements of sap flow can lead to an overestimation of transpiration rate by up to $35 \%$. In the present study, the values converted to average transpiration blades were 3.45 and $2.39 \mathrm{~mm} \mathrm{~d}^{-1}$ for the CP and SP areas, respectively. In comparison, Nassif et al. (2014), used sap flow sensors and recorded transpiration rates varying between 3.4 and $4.2 \mathrm{~mm} \mathrm{~d}^{-1}$ for sugarcane grown in the municipality of Piracicaba.

\section{Crop evapotranspiration}

The analysis of relationship between the evapotranspiration of crop measured using the Bowen ratio method (ETC-BRM) and the sum of the sap flow based on an estimate of the 
evaporation of soil water (ETc-FS + EV) showed coefficients of determination of 0.65 and 0.69 , and angular coefficients of 1.01 and 0.96 for the CP and SP treatments, respectively (Fig 4A, B). These values indicate that evaporation model used in conjunction with sap flow sensors (to measure transpiration) can be applied to obtain estimates of the water demand of crops with good performance. We found that the ETc of the area managed with a straw cover was also superior to that of the area without straw, which may have been due to the higher LAl and soil water content of the area with straw and to the lower evaporation of water from the soil when the straw is retained.

The average ETc-BRM values for the $\mathrm{CP}$ and SP treatments were 3.52 and $2.01 \mathrm{~mm} \mathrm{~d}^{-1}$, respectively, whereas those based on the sum of the sap flow plus the evaporation of water from the soil were 3.66 and $2.53 \mathrm{~mm} \mathrm{~d}^{-1}$, respectively. Similar values (a mean ETc of $3.48 \mathrm{~mm} \mathrm{~d}^{-1}$ ) were obtained by Nassif et al. (2014) on the same sugarcane variety. Silva et al. (2012), recorded a mean ETc value of $3.1 \mathrm{~mm} \mathrm{~d}^{-1}$ under similar climatic conditions in semi-arid Brazil. Watanabe et al. (2004), obtained a mean ETc value of $4 \mathrm{~mm} \mathrm{~d}^{-1}$ in semiarid region of northeast Thailand. Furthermore, using the Bowen ratio method, Inman-Bamber and McGlinchey (2003) recorded a mean ETc value of $5.2 \mathrm{~mm} \mathrm{~d}^{-1}$ under the climatic conditions of Kalamia (Australia) and Simunye (Swaziland in the southern region of Africa).

However, we obtained a lower ETc values in the present study. It can probably be attributed to the fact that we determined ETC during the maturation period of the sugarcane, based on measurements of sap flow. When ETc was determined using the BRM method during the period of maximum water demand, there were days when high values of ETc close to $7 \mathrm{~mm} \mathrm{~d}^{-1}$ were obtained. Similar results were obtained by Silva et al. (2013), who showed that at the beginning of the cycle of culture, the ETc was low due to a reduced $\mathrm{LAI}$, and that with progression of the cycle, the ETc reaches maximum values of 6 to $8 \mathrm{~mm} \mathrm{~d}^{-1}$. For sugarcane grown in the Piracicaba region, Nassif et al. (2014) also recorded values of ETc greater than $7 \mathrm{~mm} \mathrm{~d}$. They attributed these high values to the masses of dry air in the region and high temperature and solar radiation, which results in high atmospheric demand. These are associated with the availability of water in the soil, which favors an increase in ETc.

\section{Materials and methods}

\section{Location and experimental design}

A field experiment was carried out in an irrigated second ratoon sugarcane field ( $2.5 \mathrm{ha}$ ), planted with the cultivar RB867515 at October 16, 2012. This cultivar is widely used and accounts for $27 \%$ of Brazilian sugarcane fields. This experiment trial was part of a long-term sugarcane experiment, carried out from October 2012 to July 2016. Planting was arranged in single row spacing of $1.4 \mathrm{~m}$, distributing 13-15 buds per linear meter to a depth of 0.25 $\mathrm{m}$. The experiment was started on July 17, 2014, with harvest on June 8, 2015 (after a total of 327 days).

The experimental site was located at the Department of Biosystems Engineering of the College of Agriculture "Luiz de Queiroz" (ESALQ/USP), Piracicaba, São Paulo (Lat: $22^{\circ} 41^{\prime} 55^{\prime \prime}$ S Lon: $47^{\circ} 38^{\prime} 34^{\prime \prime} \mathrm{W}$ Alt: $\left.540 \mathrm{~m}\right)$. The climate is characterised as hot and wet summer and dry winter (Cwa Köppen classification), and the soil is a Hapludox. The chemical characterization was performed in the second quarter of 2014 (Table 1). The samples were reticulated at $20 \mathrm{~cm}$ from the planting line and at depths of 0-20 and 20-40 $\mathrm{cm}$. Fertilisation and agricultural pesticides were applied at the beginning of plant and ratooning cane cycles according to conventional practices in the state of São Paulo State (Ripoli et al., 2007): (i) surface liming (2.5 ton ha-1); (ii) 12-612 NPK ( 1 ton ha-1) incorporated between rows (ratoon) and in-furrow (plant); (iii) herbicides and pesticides were applied continuously throughout the season.

The experiment had two treatments, one with straw cover (CP) and one without straw cover (SP). Attempting to represent a mechanised sugarcane field, $9 \mathrm{t} \mathrm{ha}^{-1}$ of straw were left and spread homogeneously in the $\mathrm{CP}$ area, while all the straw material was removed on the SP area (bare soil). The straw material was composed of dried leaves and top parts of sugarcane stalks previously harvested on the first sugarcane ratoon season (17-Oct-2013 to 16-Jul-2014). Crop evapotranspiration, transpiration and soil moisture were monitored throughout the season to quantify the water flux in the soil-sugarcane-atmosphere system and schedule irrigation application to keep soil moisture in optimum conditions. Crop leaf area index (LAI) was monitored by Licor LAI-2000.

\section{Evaporation of water from the soil}

Evaporation of soil water was estimated based on the approach suggested by Van Keulen and Seligman (1987), where maximum soil evaporation (ESp, Equation 1) is converted into real evaporation by a reduction factor $\left(R_{d, e}\right.$, Equation 2), calculated as a function of the relative water content of the soil, which in turn takes into account the ratio between the current volumetric content $\left(\theta_{\mathrm{v}}\right)$ of water in the 0 to $10 \mathrm{~cm}$ layer of soil and the humidity at the point of saturation $\left(\theta_{\text {sat }}\right)$.

$$
\begin{array}{r}
\mathrm{ESp}=\mathrm{ET} \cdot \mathrm{e}^{-0.7 \cdot \mathrm{LAl}} \\
\mathrm{d}_{\mathrm{d}, \mathrm{e}}=\frac{1}{1+\left[3.6073\left(\frac{\theta_{\mathrm{v}}}{\theta_{\mathrm{sat}}}\right)\right]^{-9.3172}}
\end{array}
$$

In Equation 1, ET is the evapotranspiration of sugarcane using the parameterized Penman-Monteith method and LAI is the leaf area index.

To estimate the evaporation rate of soil with a surface cover of straw, Adams et al. (1976) suggested that the mass of straw on the soil and the percentage cover of the crop on the surface should be considered, as shown in equation (3). In the present study, we used the method of Van Keulen and Seligman (1987) (Equation 1) in combination with the proposal of Adams et al. (1976) to obtain a modifier for Equation 1 that takes into account the presence of straw on the soil surface (Eq. 3).

$$
E c m=E S p \exp \left[-1.7 \times 10^{-2}(S)-2.2 \times 10^{-4 *}(\mathrm{MR})\right]
$$

In Equation 3, Ecm is the product of the estimated potential evaporation and its fractional reduction in evaporation resulting from the shade of the plant canopy and the straw; $S$ is the shadow percentage (\%), estimated using Equation 4; 
ESp is the potential evaporation ( $\mathrm{mm} /$ day) obtained using Equation 1, and MR is the mass of straw (t/ha), $9 \mathrm{t} / \mathrm{ha}$ of cane straw were kept.

In the present study, it was assumed that the percentage shade was proportional to the radiation absorbed by the residual straw, from which it can be deduced that $S \%$ can be obtained using the following equation:

$$
S=\left(Q g \cdot(1-r) \cdot\left(1-e^{-k . L A I}\right)\right) \cdot 100
$$

Where; $\mathrm{Qg}$ is the global radiation $\left(\mathrm{w} / \mathrm{m}^{2}\right), \mathrm{K}$ is the extinction coefficient, $r$ is the albedo, and LAl is the leaf area index.

\section{Sap flow}

Transpiration was determined by the heat balance method using Dynamax Inc. sap flow sensors. Three sensors were installed in each treatment in the stalks of sugar cane in the region of internodes in order to prevent the sprouting of stem buds. Measurements were performed for 47 days. The transpiration of culture was also analyzed by means of a completely randomized experiment during 5 periods of 9 days (summation of transpiration during the 9 days) and with the three replicates, where three sensors installed in each treatment.

The sap flow calculation was based on the heating of a stem segment via a heat source $(P)$, and the thermal energy was dissipated by driving in axial shafts ( $Q i$ and $Q s$ ) and radial (Qr) convection, and also in through the sap flow (QF). The sap flow (FS) was determined using Equation 5, as described by Sakuratani and Abe (1985):

$$
\mathrm{FS}=\frac{P-Q a-Q r}{d T . c p}
$$

Where, FS is the sap flow in $\mathrm{kg} \mathrm{s}^{-1} ; \mathrm{P}$ is the applied power (W); Qa (Qs + Qi) is the flow in watts of energy dissipated axially, obtained by summing the upper axial flow (Qs) and lower (Qi); $Q r$ is the flow of energy dissipated radially; $d T$ is the temperature difference between the upper and lower end of the sensor; and $\mathrm{cp}$ is the specific heat of water (4.186 $\times 10^{-3} \mathrm{~J} \mathrm{~kg}^{-1}{ }^{\circ} \mathrm{C}^{-1}$ ).

Axial flow (Qa) was obtained using Equation 6:

$$
\mathrm{Qa}=K s t \cdot A c \frac{(\Delta T b-\Delta T a)}{\Delta x}
$$

Where; Kst is the thermal conductivity of the stem, which is considered to be $0.54 \mathrm{Wm}^{-1}{ }^{\circ} \mathrm{C}^{-1}$ (Sakuratani and Abe, 1985), $\mathrm{Ac}$ is the area of the cross section of the stem (average plant: $\left.7,694 \times 10^{-4} \mathrm{~m}^{2}\right)$, and $\Delta \mathrm{x}$ is the distance between the thermocouples ( $3 \mathrm{~mm}$ ).

The radial flow (Qr) was calculated using Equation 7:

$$
Q r=K r * \Delta T r a d
$$

Where; $\mathrm{Kr}$ is the radial thermal conductivity of the heat meter and can be obtained under conditions of null or tiny sap flow sensor for each installation, as shown in Equation 8:

$$
K r=(P-Q a) \Delta T r a d
$$

The determination of $\mathrm{Kr}$ was performed using data collected between 03:00 am and 05:00 am, a time period considered to coincide with zero or negligible sap flow. Evaluation of the data for high and low sap rising rates followed the approach described by Marin et al. (2008).

Transpiration rates determined using the sap flow sensors were integrated to obtain the results in terms of $L$ stalk $^{-1} \mathrm{~d}^{-1}$. Immediately after this procedure, the leaf area of each stem was measured and water loss per square meter of leaf per day was estimated. This value was then multiplied by the area in question to determine the consumption of water in terms $\mathrm{mm}$ per crop. The average area of leaves on the stem when sap flow was measured was 0.459 and $0.465 \mathrm{~m}^{2}$ plant ${ }^{1}$, for an area $\mathrm{CP}$ and SP, respectively.

\section{Culture evapotranspiration (ETC)}

A Bowen ratio method was used to evaluate the mass and energy exchanges over the field with two forced ventilation psychrometers (Marin et al. 2001). Measurements of dry and wet temperatures $\left({ }^{\circ} \mathrm{C}\right)$ were performed based on a height difference of $1 \mathrm{~m}$, with the lower measurement maintained at canopy level, following sugarcane plant growth. A net radiometer and two soil heat flux instruments were also installed. The crop evapotranspiration was determined according to Equation 9:

$$
\mathrm{LE}=\frac{R n-G}{1+\beta} \rightarrow \mathrm{ETc}=\frac{R n-G}{\lambda(1+\beta)}
$$

Where; $R n$ is the net radiation ( $M J m^{-2} d^{-1}$ ), $G$ is the soil heat flux ( $\left.M J m^{-2} d^{-1}\right), \beta$ is the Bowen ratio, LE is the latent heat flux ( $M J \mathrm{~m}^{-2} \mathrm{~d}^{-1}$ ), and $\lambda$ is the latent heat of evaporation. The Bowen ratio values $(\beta)$ were calculated at $15 \mathrm{~min}$ interval based on the temperature gradient values $(\Delta T)$, the vapor pressure gradient values $(\Delta \mathrm{e})$, and psychometric constant $(\gamma)$, according to Equation 10 :

$$
\beta=\gamma \frac{\Delta T}{\Delta e}
$$

The Bowen ratio method can show some variability in values, which was checked according to the procedure described by Perez et al. (1999). In periods when the measures showed such variability, interpolations were performed. For periods of such undesired variability exceeding $2 \mathrm{~h}$, data for the entire day were was discarded.

\section{Statistical analysis}

Only daytime data were used to compute ETc using the BRM method. ETc values measured with the BRM method were examined and compared with the sum of the soil evaporation and crop transpiration (sap flow) data. To verify the consistency of the models used, the observed values were submitted to regression and compared with the values measured in the field for both treatments. The accuracy of the models can be verified by means of the determination coefficient $R^{2}$ and the angles $a$ and $b$.

The transpiration measured with the sap flow sensors was also compared among the treatments, in which case the Tukey test was used at $5 \%$ probability. The results were subjected to statistical analysis using the Sisvar program (Ferreira, 2011). 


\section{Conclusions}

The cultivation of sugarcane using a cover of vegetable residues favors an increase in transpiration and ETc and reduces the evaporation of water from the soil.

The soil water evaporation model applied in the present study can be used in conjunction with sap flow data for ETc.

\section{Acknowledgments}

The authors express their gratitude to the following organizations: National Council of Scientific and Technological Development (CNPq), Foundation for Research Support of the State of São Paulo (FAPESP) process no $2014 / 05887-6$ for the support extended for this study.

\section{References}

Adams JE, Arkin GF, Ritchie JT (1976) Influence of row spacing and straw mulch on first stage drying. Soil Sci Soc Am J. 40:436-442.

Allen RG, Pereira LS, Raes D, Smith M (1998) Crop evapotranspiration: Guidelines for computing crop water requirements, $F A O$. Rome.

Chabot R, Bouarfa S, Zimmer D, Chaumont C, Moreau S (2005) Evaluation of the sap flow determined with a heat balance method to measure. Agr Water Manage. 75:10-24.

[CONAB] Companhia Nacional de Abastecimento. (2017). Acompanhamento da safra brasileira de grãos: Safra 2016/17. 144.

[FAOSTAT] Food and Agriculture Organization. 2016. Statistical database. FAOSTAT. (12 January 2016; http://faostat.fao.org/).

Denmead OT, Mayocchi CL, Dunin FX (1997) Does green cane harvesting conserve soil water? Proc Conf Aus Soc Sugar Tech. 19: 139-146.

Dias, MO, Cunha, MP, Jesus, CD, Rocha, GJ, Pradella JGC, Rossell, CE, Bonomi, A (2011) Second generation ethanol in Brazil: can it compete with electricity production? Biores Technol. 102(19): 8964-8971.

Ferreira DF (2011) Sisvar: a computer statistical analysis system. Ciênc Agrotec. 35: 1039-1042.

Gava, GJDC, Trivelin, PCO, Oliveira, MWD, Penatti, CP (2001). Growth and accumulation of nitrogen by sugarcane cultivated in soil covered with cane trash. Pesq Agrop Bras, 36(11): 13471354.

Graham MH, Haynes RJ, Meyer JH (2002) Changes in soil chemistry and aggregate stability induced by fertilizer applications, burning and trash retention on a long-term sugarcane experiment in South Africa. Eur J Soil Sci. 53(4): 589-598.

Inman-Bamber NG, McGlinchey MG (2003) Crop coefficients and water-use estimates for sugarcane based on long-term Bowen ratio energy balance measurements. Field Crops Res. 83:125138.

Kingston G (2014) Mineral Nutrition of Sugarcane. In: Moore PH, Botha FC. (ed.). Sugarcane: Physiology, Biochemistry, and Functional Biology 5:85-120.

Leal MRL, Galdos MV, Scarpare FV, Seabra JE, Walter A, Oliveira CO (2013). Sugarcane straw availability, quality, recovery and energy use: a literature review. Biomass Bioenergy. 53: 11-19. Leuzinger S, Vogt R, Körner C (2010) Tree surface temperature in an urban environment. Agric Meteorol. 150:56-62.
Marin FR, Angelocci LR, Coelho-Filho MA, Villa Nova NA (2001) Construction and evaluation of aspired thermocouple psychrometer. Sci Agric. 58:839-844.

Marin FR, Ribeiro RV, Angelocci LR, Righi EZ (2008) Fluxo de seiva pelo método de balanço de calor: base teórica, qualidade das medidas e aspectos práticos. Bragantia Campinas. 67:1-12.

Marin FR, Jones JW (2014) Process-based simple model for simulating sugarcane growth and production. Sci Agric. 71:116.

Nassif DSP, Marin FR, Costa LG (2014) Evapotranspiration and transpiration coupling to the atmosphere of sugarcane in southern Brazil: scaling up from leaf to field. Sugar Tech. 16:250-254.

Olivier FC, Singels A (2012) The effect of crop residue layers on evapotranspiration, growth and yield of irrigated sugarcane. Water SA. 38: 77-86.

Peres JG, Souza CF, Lavorentt NA (2010) Avaliação dos efeitos da cobertura de palha de cana-de-açúcar na umidade e na perda de água do solo. Eng Agríc. 30:875-886.

Perez PJ, Castellvi F, Ibañez M, Rosell JI (1999) Assessment of reliability of Bowen ratio method for partitioning fluxes. Agric For Meteorol. 97:141-150.

Ripoli TCC, Ripoli MLC, Casagrandi DV, Ide BY (2007). Plantio de cana-de-açúcar: Estado da arte. Piracicaba.

Sakurantani T, Abe J (1985) A heat balance method for measuring water sap flow in the stem of intact plants and its application to sugarcane plants. Jap Agric Res Quart. 19:9297.

Silva TGF, Moura MSB, Zolnier S, Soares JM, Viera VJS, Farias Junior WG (2012) Requerimento hídrico e coeficiente de cultura da cana-de-açúcar irrigada no Semiárido brasileiro. $\mathrm{R}$ Bras Eng Agríc Amb. 16: 64-71.

Silva TGF, Zolnier S, Moura MSB, Souza LS (2013) Sazonalidade do Controle de Evapotranspiração pela Cana-de-Açúcar Irrigada e Características Aerodinâmicas da Cultura no Semiárido brasileiro (Seasonal Evapotranspiration Control by Irrigated Sugarcane). R Bras Geog Físic. 6:621-634.

Thorburn PJ, Probert ME, Lisson S, Wood AW, Keating BA (1999) Impacts of trash retention on soil nitrogen and water: an example from the Australian sugarcane industry. Proc S Afr Sugar Technol Assoc. 73 75-79.

Van Keulen H, Seligman NG, (1987) Simulation of Water Use Nitrogen Nutrition and Growth of a Spring Wheat Crop, Simulation Monograph, Pudoc, Wageningen.

Vasconcelos ACM, Casagrande AA, Perecin D, Jorge LAC, Landell MGA (2003) Avaliação do sistema radicular da cana-de-açúcar por diferentes métodos. $\mathrm{R}$ Bras Ci Solo. 27:849-858.

Van Antwerpen $\mathrm{R}$, Thorburn PJ, Horan $\mathrm{H}$, Meyer JH, Bezuidenhout CN (2002) The impact of trashing on soil carbon and nitrogen: ii: Implications for sugarcane production in South Africa. In Proc S Afr Sug Technol Ass. 76: 269-280.

Wang D, Gartung J (2010) Infrared canopy temperature of earlyripening peach trees under postharvest deficit irrigation. Agr Water Manage. 97:1.787-1.794.

Walter A, Galdos MV, Scarpare FV, Leal MRLV, Seabra JEA, Cunha MP, Oliveira COF (2014) Brazilian sugarcane ethanol: developments so far and challenges for the future. WIREs: Energy Environment. 3(1): 70-92.

Watanabe K, Yamamoto T, Takashi Yamada L (2004) Changes in seasonal evapotranspiration, soil water content, and crop coefficients in sugarcane, cassava, and maize fields in Northeast Thailand. Agr Water Manage. 67:133-143. 